\title{
Groundwater quality and vulnerability assessment in west Luxor Governorate, Egypt
}

\author{
Salman A. Salman ${ }^{\mathrm{a}, 1}$, Mercedes Arauzo ${ }^{\mathrm{b}, 2}$, Ahmed A. Elnazer ${ }^{\mathrm{a}, *}$ \\ ${ }^{\text {a } G e o l o g i c a l ~ S c i e n c e s ~ D e p a r t m e n t, ~ N a t i o n a l ~ R e s e a r c h ~ C e n t r e, ~ D o k k i, ~ G i z a, ~ E g y p t ~}$ \\ ${ }^{\mathrm{b}}$ Dpto. de Planta, Suelo y Calidad Ambiental, Instituto de Ciencias Agrarias ICA-CSIC, Serrano 115 dpdo., 28006 Madrid, Spain
}

\section{A R T I C L E I N F O}

\section{Keywords:}

Groundwater vulnerability

Nitrate

Heavy metals

Hydrogeological factors

Land use

Egypt

\begin{abstract}
A B S T R A C T
Groundwater is the main source of water for different purposes in the desert areas of Egypt. The agricultural and different human activities in line with hydrological characteristics have influenced the quality of this water resource. The main aim of this work was the determination of groundwater quality and vulnerability to pollution in west Luxor Governorate, Egypt. For completion of this work, 50 boreholes were sampled during October 2014 and groundwater samples were analyzed chemically. Hydrological, topographic, lithological, climatic conditions and land use data, which considered key factors for pollutants transport, were also collected for building groundwater vulnerability maps. The results revealed high levels of groundwater pollution with $\mathrm{NO}_{3}{ }^{-}$, $\mathrm{Cd}$ and $\mathrm{Pb}$, as well as increased levels of total dissolved solids. The map of intrinsic groundwater vulnerability (based on the IV index; Arauzo 2017) showed medium and high levels of vulnerability associated with natural factors in $62 \%$ and $38 \%$ of the area, respectively. The map of specific groundwater vulnerability (based on the LU-IV procedure; Arauzo 2017) indicated that $52 \%$ of the area showed high to extreme levels of vulnerability to nitrate pollution from nonpoint sources. From this, it was concluded that the study area can be considered as Nitrate Vulnerable Zone (NVZ) and, therefore, specific measures (including optimization of water and N-fertilizers applications) must be taken in order to restore water quality.
\end{abstract}

\section{Introduction}

Wastewater application, agricultural activities and urbanization can produce different types of pollutants which impact adversely groundwater quality. Nitrate and heavy metals are considered the most widespread hazardous pollutants in water bodies. Nitrate pollution from diffuse agricultural sources is the main cause of the deterioration of water quality and contributes to the process of eutrophication (Sutton et al., 2011). Water supplies pollution with nitrate can cause many health problems such as methemoglobinemia (Camargo and Alonso, 2006). Water pollution with heavy metals was recorded elsewhere and has been linked to many health problems (FernándezLuqueño et al., 2013; Melegy et al., 2014; Hasan et al., 2016). It can cause Alzheimer's and Parkinson's disease, muscular dystrophy (Verma and Dwivedi, 2013), renal failure and various cancers (Paul, 2017).

The quaternary aquifer water in the River Nile valley was assessed by many authors. The groundwater is highly polluted to an alert level for human consumption at Sohag Governorate (Ahmed, 2009; Melegy et al., 2014). El-Aassar et al. (2016) referred to the pollution of groundwater with nitrate in Assuit to the agricultural activities. Asmoay (2017) pointed out the pollution of groundwater with $\mathrm{Cd}$ and $\mathrm{Pb}$ to carcinogenic concentrations at El Minya Governorate. The groundwater vulnerability was assessed by applying DRASTIC model in the Nile Delta (Gemail et al., 2017), Sohag (Ahmed, 2009), Assiut (El Tahlawi et al., 2016; El-Aassar et al., 2016). The applied the DRASTIC model indicated the vulnerability of groundwater in the studied sites.

Environmental factors, such as land-use pattern, type of aquifer, and soil-drainage capacity, affect the level of groundwater contamination (Dubrovsky and Hamilton, 2010; Arauzo et al., 2011; Arauzo and Martínez-Bastida, 2015). Groundwater vulnerability assessment is considered the initial step in understanding and evaluating the susceptibility of an aquifer to contamination (Kang et al., 2016). Therefore, vulnerability mapping has become an important demand during recent years (Rahman, 2008). The use of Geographic Information System (GIS) tools have contributed to a great extent in the determination of the groundwater vulnerability to pollution. Many models have been used

\footnotetext{
* Corresponding author.

E-mail addresses: sa.salman@nrc.sci.eg (S.A. Salman), mercedes.arauzo@csic.es (M. Arauzo), ah.el-nazer@nrc.sci.eg (A.A. Elnazer).

${ }^{1}$ National Research Centre (NRC), 33 El Bohouth St. (former El Tahrir St.)- Dokki, Giza. POB: 12622, Dokki. Giza, Egypt.

${ }^{2}$ Instituto de Ciencias Agrarias, Dpto. de Planta, Suelo y Calidad Ambiental, Instituto de Ciencias Agrarias ICA-CSIC, Serrano 115 dpdo., 28006 Madrid, Spain.
} 
worldwide for determination of groundwater vulnerability during the last decades, such as DRASTIC, GOD and GALDIT (Moghaddam et al., 2015). The recently published LU-IV procedure by Arauzo (2017) is considered more effective than the most widely-used methods for assessing and mapping groundwater vulnerability to nitrate pollution. This novel method stands out as it meets several advantages, as it assesses intrinsic vulnerability over the entire topographical surface of the potential catchment area of an aquifer, it uses readily available parameters that provide enough data to feed the model and it is implementable within a GIS.

The aims of this study were (a) the investigation of the occurrences and sources of nitrate and heavy metals in groundwater and (b) the assessment of groundwater quality and vulnerability to pollution in west Luxor Governorate, Egypt. The LU-IV procedure was applied to assess intrinsic and specific groundwater vulnerability to nitrate pollution in this territory, increasingly affected by intensive agriculture and urban development.

\section{Materials and methods}

\subsection{Study area}

The study area is located on the west bank of the River Nile in Luxor Governorate, Egypt. It is extended between Latitudes $25^{\circ} 15^{\prime}$ and $25^{\circ}$ $55^{\prime}$ and Longitudes $32^{\circ} 24^{\prime}$ and $32^{\circ} 48^{\prime}$ (Fig. 1). The area is characterized by an arid climate and intensive agricultural, touristic, and urbanization activities. Lithologically, the study area is composed of sedimentary deposits that range in age from Eocene to Recent (Fig. 2).

The desert fringes reclamation in the study area depends mainly on the Quaternary aquifer groundwater resources. The water-bearing sediments of the Quaternary aquifer composed mainly of gravels and sands (Fig. 3). It is underlain by the Pliocene clay (Madamud Formation) in most localities of the studied area (Ahmed and Fogg, 2014). The

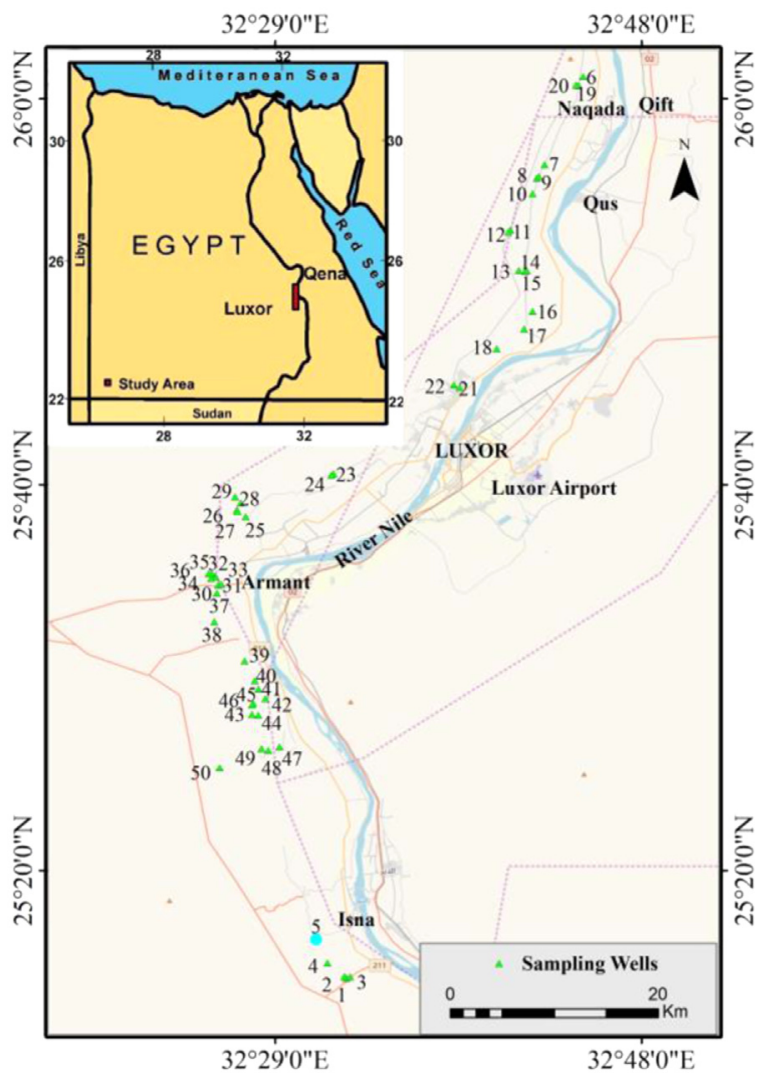

Fig. 1. Location map of the study area and sampling wells. water-bearing layer is covered by the silty clay layer (1-27 m Thick) in the old cultivated land (Floodplain) and considered a semi-confined aquifer. The silty clay layer disappeared westward near desert fringes and the aquifer becomes unconfined (Abd El-Bassier, 1997).

\subsection{Sampling and analyses}

Groundwater samples were collected from 50 boreholes in October 2014, which mainly used for irrigation and sometimes for domestic purposes. Temperature, $\mathrm{pH}$, total dissolved solids (TDS) and electrical conductivity (EC) were determined in situ using a HANNA HI 991301 $\mathrm{pH} / \mathrm{EC} / \mathrm{TDS}$ meter. In the laboratory, the samples were filtered through $0.45 \mu \mathrm{m}$ filter paper to remove suspended materials and analyzed according to APHA (1995). Sodium $\left(\mathrm{Na}^{+}\right)$and potassium $\left(\mathrm{K}^{+}\right)$were determined by flame photometer. Calcium $\left(\mathrm{Ca}^{2+}\right)$, magnesium $\left(\mathrm{Mg}^{2+}\right)$, carbonates $\left(\mathrm{CO}_{3}\right)^{2-}$, bicarbonate $\left(\mathrm{HCO}_{3}{ }^{-}\right)$and chloride $\left(\mathrm{Cl}^{-}\right)$were analyzed by titrimetric methods. Sulfates $\left(\mathrm{SO}_{4}{ }^{2-}\right)$ and nitrate $\left(\mathrm{NO}_{3}{ }^{-}\right)$were estimated by using a HANNA HI 83215 Spectrophotometer. Heavy metals were determined by using the atomic absorption spectrophotometer (Perkin Elmer 400) after acidifying the samples with $\mathrm{HNO}_{3}$ to $\mathrm{pH}<2$. The suitability of water for irrigation was determined by calculation of sodium absorption ratio (SAR) according to Richards (1954) equation (all values in meq $\mathrm{L}^{-1}$ ):

$S A R=\mathrm{Na}^{+} /\left[\left(\mathrm{Ca}^{2+}+\mathrm{Mg}^{2+}\right) / 2\right]^{1 / 2}$

\subsection{Mapping groundwater vulnerability}

The LU-IV procedure (Arauzo, 2017) was used (Fig. 4) to generate thematic maps of the intrinsic groundwater vulnerability (Step 1) and the specific groundwater vulnerability to nitrate pollution (Step 2) using ArcGIS 10.2 for Desktop (ESRI, 2013). This new two-steps GISbased method will be explained in detail below.

\subsubsection{Step 1: Intrinsic groundwater vulnerability (the IV index)}

The IV index was based on four environmental parameters that are commonly related to intrinsic groundwater vulnerability and that provide enough data, as follows:

$I V=\frac{L+D+T+P}{4}$

Where $\boldsymbol{L}, \boldsymbol{D}, \boldsymbol{T}$ and $\boldsymbol{P}$ represent the rating of the risks associated with the lithology of the vadose zone, the depth of the water table, topography (percentage of slope) and the average annual precipitation, respectively (Table 1). Five categories of different risks were used for IV index interpretation: negligible risk: 1-2; low risk: 3-4; medium risk: 5-6; high risk: 7-8; extreme risk: 9-10 (Arauzo, 2017).

The depth of the water table $(D)$ was collected from the sites of wells during the field work 2014. For mapping the risks associated with the lithology $(L)$, we used the digital version of Conoco Geologic map (CONOCO, 1987). A raster map of topographic slope (T)

was generated from a DEM (the Advanced Spaceborne Thermal Emission and Reflection Radiometer (ASTER) Global Digital Elevation Model (GDEM) with data resolution $30 \mathrm{~m}$ ) using Slope tool (Spatial Analyst Tools in ArcGIS 10.2). As a result of the extremely scarce and low annual precipitation in the study area $\left(0-15 \mathrm{~mm} \mathrm{yr}^{-1}\right)$, we opted to exclude the parameter $P$ from the algorithm of the IV index (in Eq. (1)) to avoid underestimating the weights of parameters $L, D$ and $T$ during step 2 . In this case, the risk of nitrate leaching obviously does not come from the precipitation, but from the unoptimized irrigation methods used in agriculture (whose associated risks are going to be addressed in step 2). To create the raster of the risks associated with $L, D$ and $T$, ratings for each of them (Table 1) were assigned using Reclassify (Spatial Analyst Tools). Then, the map of intrinsic groundwater vulnerability based on the IV index was created using the Raster Calculator (Spatial Analyst Tools) according to the following Equation. 


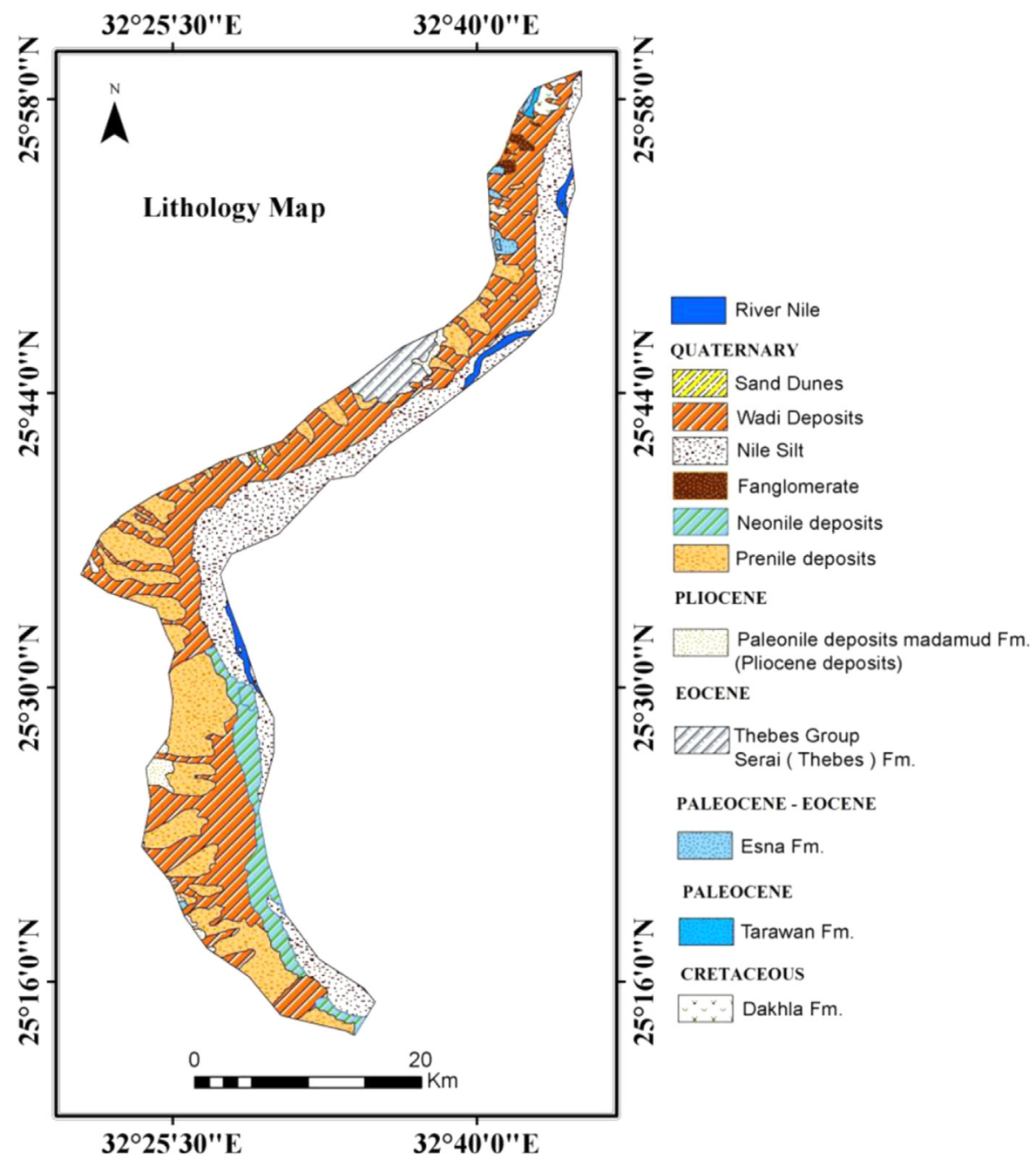

Fig. 2. Lithologic map of the study area (modified from Conoco, 1987).

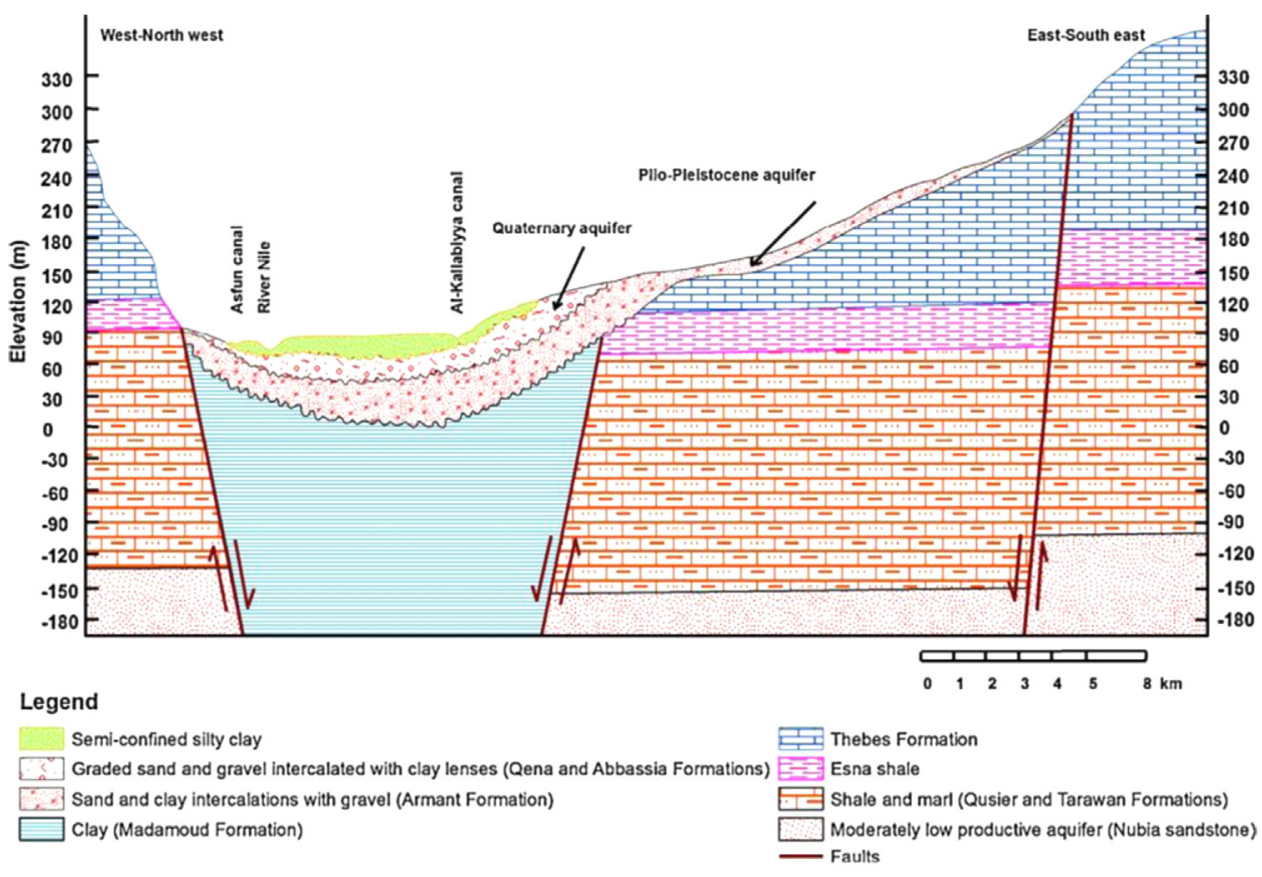

Fig. 3. Hydrogeological cross section at Luxor area (illustrated in Ahmed and Fogg, 2014). 


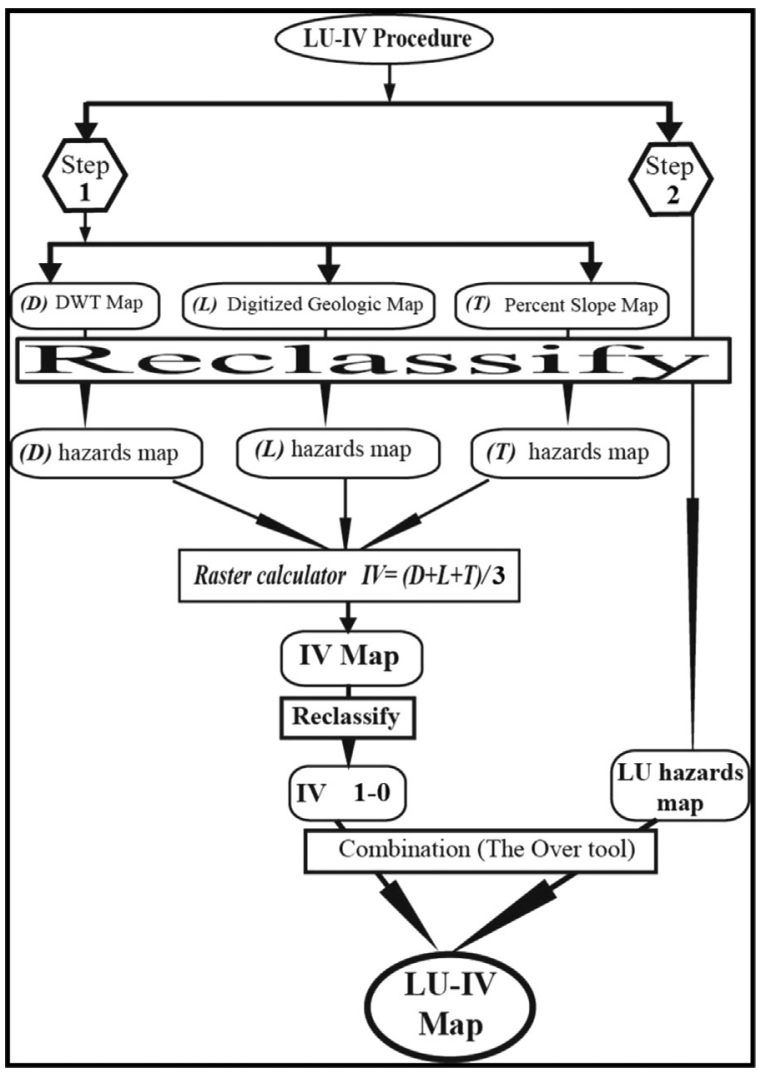

Fig. 4. LU-IV procedures simplified flow chart.

$I V=\frac{L+D+T}{3}$

\subsubsection{Step 2: Specific groundwater vulnerability to nitrate pollution}

The LU-IV procedure (Arauzo, 2017) was developed as a tool for assessing and mapping groundwater vulnerability to nitrate pollution (associated with land use) and delimiting the NVZ. This procedure combines the above mentioned intrinsic vulnerability map (Eq. (2): step 1) and the map of the risks associated with land use, using the Over tool from the Math > Logical toolset of Spatial Analyst Tools (step 2).

To create the map of risks associated with land use, the Elshayal Smart Web Online Software (version 4.86) was used to generate a highresolution Land Use map of Egypt from Google map (2017). Ratings applied to different land uses (Table 1) were assigned using Reclassify according to Arauzo's (2017) recommendations.

According to the LU-IV procedure (Arauzo, 2017), firstly we should reclassify the original cell values of the raster of intrinsic vulnerability into values of " 1 " and " 0 ", to create a new raster that we'll name as "intrinsic vulnerability 1-0". The value " 1 " represents "non-vulnerable areas" (cell values ranging from 1 to 4 , with negligible to low intrinsic vulnerabilities) and the value "0" represents "vulnerable areas" (cell values ranging from 5 to 10 , with medium to extreme intrinsic vulnerabilities). The intrinsic vulnerability $1-0$ was used as the first entry in the Over tool, while the raster of risks associated with land use was used as the second entry in the Over tool. When the Over operation is performed, for cell values in the first input that are equal to " 1 " the output value will be that of the first input. But where the cell values in the first input corresponding to "0", the output will be that of the second input raster (showing the original values of the raster of risks associated with land use). Using this procedure, we obtained a map of groundwater vulnerability to nitrate pollution associated with land use.

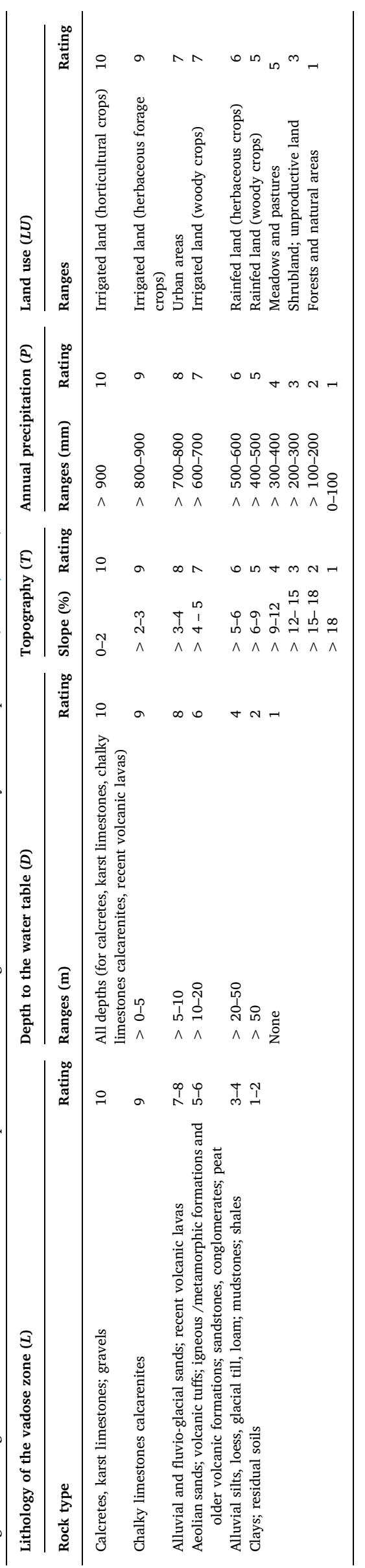




\section{Results and discussion}

\subsection{Groundwater general characterization}

Descriptive statistics of the measured water parameters and field data of sampling points are illustrated in Table 2. About $75 \%$ of the studied samples contained TDS and EC values above $1045 \mathrm{ppm}$ and $1898 \mu \mathrm{Sm}^{-1}$, respectively, indicating the high salt load in groundwater. The inter-relationships between the studied ions and also against TDS give a good indication about the geochemical processes that control the groundwater salinization in the study area (Moussa et al., 2009; Yang et al., 2016). The most contributors to water salinity in the study area are $\mathrm{Na}^{+}, \mathrm{SO}_{4}{ }^{2-}$, and $\mathrm{Cl}^{-}$(Table 2) as supported by the positive correlation with EC and TDS (Table 3). Ahmed and Fogg (2014) pointed out the importance of rock-water interaction and climate at Luxor in the geochemistry of groundwater. They pointed out the dissolution of some minerals as halite, gypsum and anhydrite. The strong positive correlation $(\mathrm{r}=+0.93)$ between $\mathrm{Na}^{+}$and $\mathrm{Cl}^{-}$indicate that the major source of these two ions is the dissolution of halite. The noticed excess of $\mathrm{Na}^{+}$ than $\mathrm{Cl}^{-}$point out the dissolution of other Na-bearing minerals in the study area sediments, cation exchange (García et al., 2001) or the application of fertilizers. The dissolution of evaporates minerals particles in the sediments is the main source of $\mathrm{Ca}^{2+}$ and $\mathrm{SO}_{4}{ }^{2+}$ (Abdalla et al., 2009) as indicated from the positive correlation $(r=+0.73)$ between them (Table 3). On the other hand, the arid climate of the study area (negligible precipitation and high temperature) led to the extent of the capillary zone to the surface and hence high evaporation of water (Ahmed and Fogg, 2014). The significate positive correlation between TDS and $\mathrm{Cl}^{-}(\mathrm{r}=+0.91)$ points out the role of the evaporation process in the salinization and mineralization of groundwater in the study area. The application of chemical fertilizers also contributes to the elevated levels of TDS, $\mathrm{SO}_{4}{ }^{2-}$ and $\mathrm{Cl}^{-}$in the groundwater of the study area (Ahmed and Fogg, 2014). Besides, this can be supported by the positive correlation between $\mathrm{NO}_{3}{ }^{-}$and both of $\mathrm{SO}_{4}{ }^{2-}(\mathrm{r}=+0.33)$ and $\mathrm{Cl}$ $(\mathrm{r}=+0.36)$.

The high load of salts in most water samples (Table 2) rendered them unsuitable for drinking based on WHO (2011) guidelines. In addition, its use as irrigation water may present detrimental effects on soil and irrigation facilities as EC $>2250 \mu \mathrm{sm}^{-1}$ and $\mathrm{SAR}>18$ (Richards, 1954).

\subsection{Specific contaminants: nitrate and heavy metals}

Groundwater is affected by nitrate pollution because its nitrate concentration (Table 2) mostly exceeds $50 \mathrm{mg} \mathrm{L}^{-1}$ (Council of the European Communities, 1991; WHO, 2011). Water nitrate within the range of $25-50 \mathrm{mg} \mathrm{L}^{-1}$ can be also considered at risk of becoming polluted (European Commission, 2000). Groundwater nitrate contents in the study area revealed high levels of pollution $\left(\left[\mathrm{NO}_{3}{ }^{-}\right]\right.$ $\geq 50 \mathrm{mg} \mathrm{L}^{-1}$ ) in 28 samples, with $\mathrm{NO}_{3}{ }^{-}$levels of up to $418 \mathrm{mg} \mathrm{L}^{-1}$ (Table 2). Also, 11 of the sampled wells were at risk of being affected by nitrate pollution $\left.\left(25 \leq \mathrm{NO}_{3}^{-}\right]<50 \mathrm{mg} \mathrm{L}^{-1}\right)$. The observed $\mathrm{NO}_{3}{ }^{-}$values give an alert about the danger of using this water for domestic purposes. The consumption of polluted water with $\mathrm{NO}_{3}{ }^{-}$can cause multiple sclerosis, gastric cancer, thyroid gland hypertrophy, NonHodgkin lymphoma (Wolfe and Patz, 2002; Suthar et al., 2009) and methemoglobinemia in infants (Sajil et al., 2014).

The map of nitrate levels in groundwater (Fig. 5) showed very elevated concentrations in the most of the study area; while $91.3 \%$ of the area was affected by pollution and $7.2 \%$ was at risk of being affected. This may be mainly related to intensive agricultural development, characterized by the multitude of small farms, which can affect $\mathrm{N}$-leaching rates and nitrate distribution in the underlying aquifer. Egypt is one of the largest consumers of chemical fertilizers in the world, especially nitrogen fertilizers, which increased from $500 \mathrm{t}$ in 1980 to $1100 \mathrm{t}$ in 2009 (Abd El Hadi and Marchand, 2013). It also was 
Table 3

Correlation matrix between the studied parameters.

\begin{tabular}{|c|c|c|c|c|c|c|c|c|c|c|c|c|c|c|c|c|c|}
\hline & WD & DWT & $\mathrm{pH}$ & TDS & EC & $\mathrm{Ca}^{2+}$ & $\mathbf{M g}^{2+}$ & $\mathrm{Na}^{+}$ & $\mathbf{K}^{+}$ & $\mathrm{HCO}_{3}^{-}$ & $\mathrm{SO}_{4}{ }^{2-}$ & $\mathrm{Cl}^{-}$ & $\mathrm{NO}_{3}^{-}$ & $\mathrm{Cr}$ & Mn & $\mathbf{P b}$ & Cd \\
\hline WD & 1.00 & & & & & & & & & & & & & & & & \\
\hline DWT & -0.03 & 1.00 & & & & & & & & & & & & & & & \\
\hline $\mathrm{pH}$ & 0.03 & -0.23 & 1.00 & & & & & & & & & & & & & & \\
\hline TDS & -0.22 & 0.04 & 0.13 & 1.00 & & & & & & & & & & & & & \\
\hline EC & -0.24 & 0.03 & 0.18 & $0.99^{\text {** }}$ & 1.00 & & & & & & & & & & & & \\
\hline $\mathrm{Ca}^{2+}$ & -0.18 & 0.29 & -0.27 & $0.73^{\text {kik }}$ & $0.69^{* *}$ & 1.00 & & & & & & & & & & & \\
\hline $\mathrm{Mg}^{2+}$ & -0.21 & 0.00 & -0.25 & $0.70^{\text {** }}$ & $0.67^{\text {*** }}$ & $0.80^{\text {*** }}$ & 1.00 & & & & & & & & & & \\
\hline $\mathrm{Na}^{+}$ & -0.16 & 0.28 & 0.00 & $0.88^{\text {** }}$ & $0.87^{\text {** }}$ & $0.66^{\text {** }}$ & $0.57^{\text {** }}$ & 1.00 & & & & & & & & & \\
\hline $\mathbf{K}^{+}$ & -0.20 & 0.11 & 0.11 & $0.48^{* * *}$ & $0.46^{* *}$ & $0.39^{* * *}$ & $0.30^{*}$ & $0.45^{* * *}$ & 1.00 & & & & & & & & \\
\hline $\mathrm{HCO}_{3}^{-}$ & -0.06 & -0.09 & 0.17 & -0.07 & -0.07 & -0.25 & -0.21 & -0.11 & 0.00 & 1.00 & & & & & & & \\
\hline $\mathrm{SO}_{4}{ }^{2-}$ & -0.19 & 0.27 & 0.00 & $0.81^{* * *}$ & $0.81^{* * *}$ & $0.73^{\text {*** }}$ & $0.60^{\text {** }}$ & $0.92^{k * k}$ & $0.42^{\text {** }}$ & $-0.28^{*}$ & 1.00 & & & & & & \\
\hline $\mathrm{Cl}^{-}$ & -0.13 & 0.21 & -0.13 & $0.91^{* *}$ & $0.88^{\text {** }}$ & $0.75^{* *}$ & $0.71^{\text {** }}$ & $0.93^{\text {kn }}$ & $0.40^{\text {** }}$ & -0.16 & $0.80^{\text {kn }}$ & 1.00 & & & & & \\
\hline $\mathrm{NO}_{3}^{-}$ & -0.17 & 0.05 & -0.10 & $0.41^{* \text { * }}$ & $0.40^{\text {**ik }}$ & $0.51^{* * *}$ & $0.36^{\text {** }}$ & $0.31^{*}$ & $0.47^{\text {** }}$ & -0.16 & $0.33^{*}$ & $0.36^{*}$ & 1.00 & & & & \\
\hline $\mathrm{Cr}$ & -0.16 & -0.11 & $0.40^{\text {*** }}$ & $0.49^{\text {** }}$ & $0.52^{\text {*** }}$ & 0.26 & $0.40^{\text {** }}$ & $0.31^{*}$ & 0.18 & -0.25 & $0.38^{* * *}$ & $0.30^{*}$ & 0.17 & 1.00 & & & \\
\hline Mn & -0.13 & -0.20 & 0.07 & 0.25 & 0.23 & 0.11 & $0.36^{*}$ & 0.11 & 0.11 & -0.11 & 0.10 & 0.20 & 0.03 & $0.33^{k * *}$ & 1.00 & & \\
\hline $\mathbf{P b}$ & 0.01 & 0.51 & -0.13 & 0.10 & 0.10 & 0.26 & 0.16 & $0.35^{*}$ & 0.05 & -0.23 & $0.40^{\text {k* }}$ & 0.24 & 0.02 & -0.02 & -0.20 & 1.00 & \\
\hline Cd & -0.09 & -0.08 & $0.31^{*}$ & $0.85^{* * k}$ & $0.85^{* * *}$ & $0.61^{* * *}$ & $0.61^{\text {** }}$ & $0.66^{\text {*** }}$ & $0.44^{\text {** }}$ & -0.05 & $0.69^{\text {**** }}$ & $0.66^{k *}$ & $0.30^{*}$ & $0.64^{\text {k** }}$ & $0.32^{*}$ & -0.07 & 1.00 \\
\hline
\end{tabular}

* Correlation is significant at the 0.05 level.

** Correlation is significant at the 0.01 level.

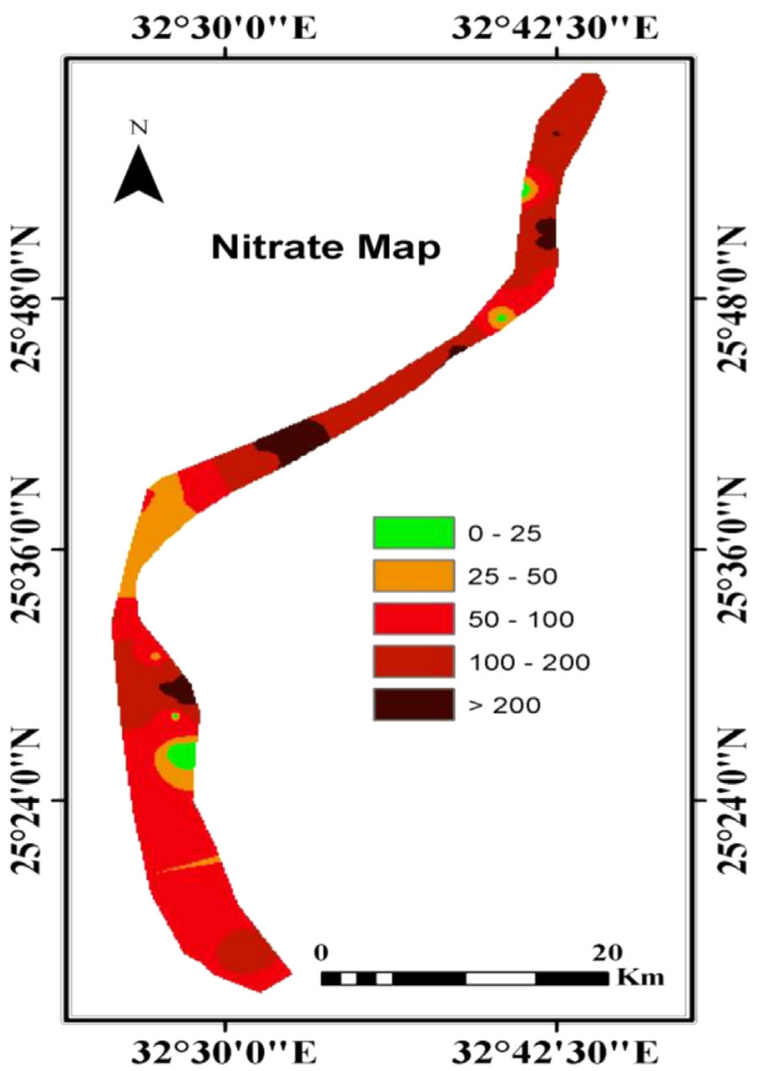

Fig. 5. Spatial distribution of $\mathrm{NO}_{3}^{-}\left(\mathrm{mg} \mathrm{L}^{-1}\right)$ in the study area.

reported that about $8-29 \%$ of these fertilizers are leached into groundwater (Li and Zhang, 1999). The positive correlations between $\mathrm{NO}_{3}{ }^{-}$and $\mathrm{Ca}, \mathrm{Mg}$ and $\mathrm{K}$ (Table 3 ) support the idea that nitrate leaching comes from fertilizers, as farmers commonly use a mixture of $\mathrm{N}$-fertilizers (as $\mathrm{MgSO}_{4}, \mathrm{KNO}_{3}$ and $\mathrm{Ca}\left(\mathrm{NO}_{3}\right)_{2}$ ). This result is consistent with those of Moussa et al. (2009) and Yang et al. (2016). The downward flow of groundwater along the Quaternary aquifer facilitates the adjective transport of nitrate from upper to lower zones of the catchment.

With regard to heavy metals in groundwater, Fe was not detected in the water samples, while $\mathrm{Mn}, \mathrm{Cr}, \mathrm{Cd}$ and $\mathrm{Pb}$ mean concentrations were 152, 26, 7 and $202 \mu \mathrm{g} \mathrm{L}^{-1}$, respectively. Observed levels of $\mathrm{Pb}$ and $\mathrm{Cd}$ were above the limits established by WHO (2011). The pollution of groundwater with these metals could be related to the widespread application of P-fertilizers, which contain considerable concentrations of $\mathrm{Cd}$ and $\mathrm{Pb}$ in Egypt (Salman et al., 2017). Mn and $\mathrm{Cr}$ are present in the ferromagnesian minerals in the sediments of the study area (Omer, 1996).

\subsection{Groundwater vulnerability}

The IV index of Arauzo (2017) for assessing and mapping intrinsic groundwater vulnerability associated with hydrological, topographic and lithological was applied to determine the vulnerable areas of the aquifer.

Topographic slope provides an indication of the ability of an area to retain water. The percentage of slope turned out to be very low in the study area (Fig. 6a). These flat territories increase the risk of retaining water for long periods, which allows high infiltration and greater potential for soluble contaminants migration. Reclassification of the raster map of topographic slope according to ratings in Table 1 revealed that the study area was nearly homogenous in relation to its extreme vulnerability associated with the topographic slope (Fig. 7a).

Depth to the water table represents the thickness of media through which water travels and interacts before reaching the groundwater (Thirumalaivasan et al., 2003). The aquifer potential protection increases with depth to the water table. The depth to the water table in the study area was less than $10 \mathrm{~m}$ in the $50 \%$ of the sampling points (Table 2 and Fig. 6b). Reclassification of the raster map of the depth of the water table according to ratings in Table 1 showed two main levels of vulnerability in the study area (from medium to high) associated to this parameter (Fig. 7b).

Lithology of the vadose zone affects directly the rate and degree of infiltration of pollutants into groundwater (Aller et al., 1987). High permeable sediments have high pollutants transport rates in comparison to low permeable ones. The study area mainly contains alluvial sediments (Fig. 6c) which have significant permeability. Reclassification of the raster map of the Lithology according to ratings in Table 1 showed levels of vulnerability from low to extreme, among the most of the territory was at a medium to high levels (Fig. 7c).

So, according to the IV index (Eq. (2)), the intrinsic groundwater vulnerability map (Fig. 8a) showed medium and high levels of vulnerability in $62 \%$ and $38 \%$ of the study area, respectively. This map (Fig. 8a) was selected to elaborate the raster intrinsic vulnerability 1-0 (Fig. 8b), which was used as the first entry in the Over tool of the LU-IV procedure. The second entry of the Over tool was based on the risk associated with land use. Land use has a great influence on groundwater 

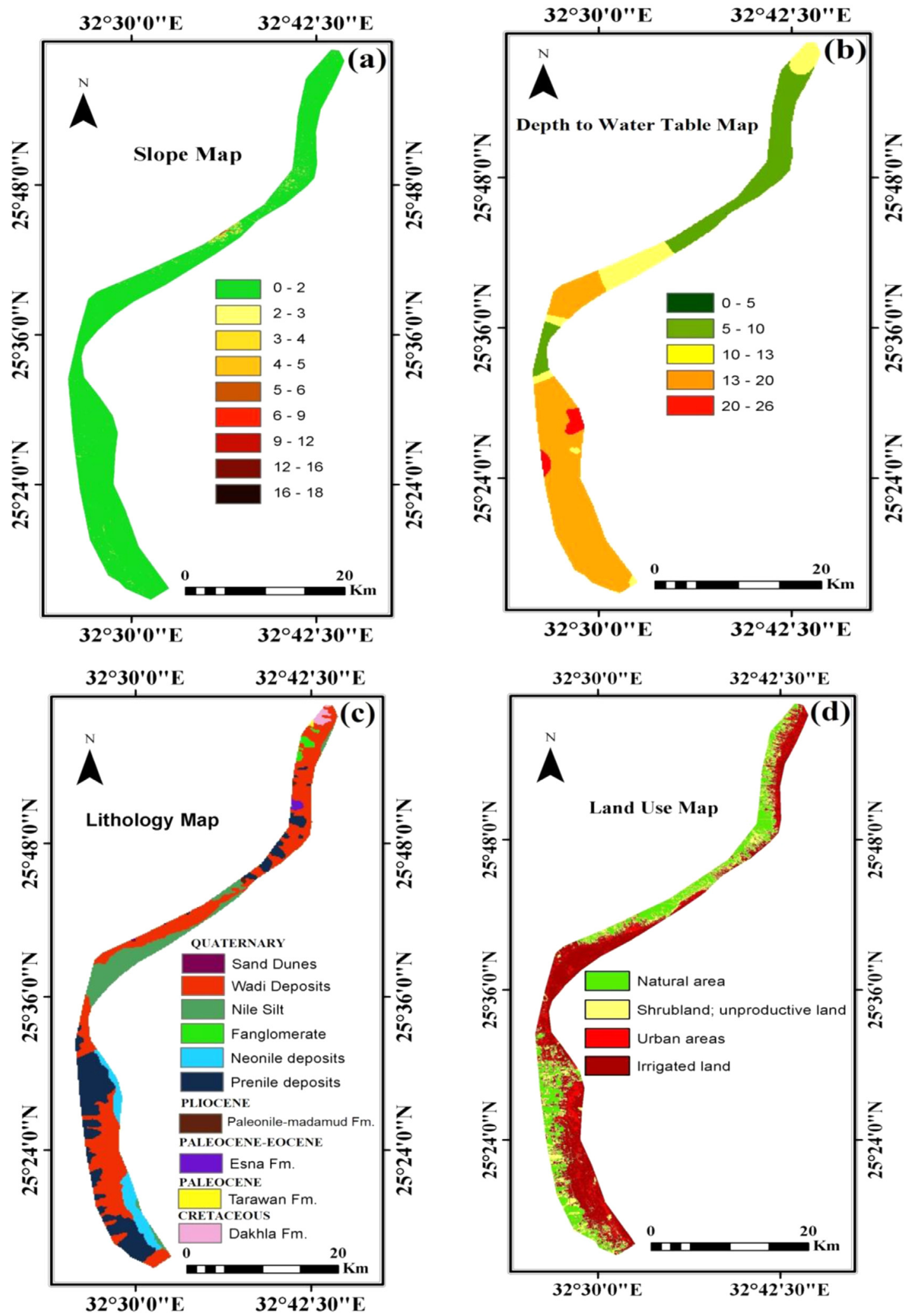

Fig. 6. Spatial distribution of (a) slope (\%), (b) depth to the water table (m), (c) lithology, (d) land uses in the study area.

hydrochemistry (Chkirbene et al., 2009). The land use map (Fig. 6d) showed the prevailing of irrigated agriculture and urbanization in the study area. Therefore, the main recharge of groundwater is from surface water canals and percolated irrigation water. Generally, urban and agricultural activities are the main contributors to groundwater pollution, especially with nitrate and heavy metals (Avtar et al., 2013).
The LU-IV procedure, for assessing and mapping groundwater vulnerability to nitrate pollution and delimiting the NVZ (Arauzo, 2017), was based on the map of the intrinsic vulnerability 1-0 (Fig. 8b) as the first entry raster and the map of the risks associated with the land use (Fig. 7d) as the second entry in the Over tool. The final map will reflect the risks associated with land use in territories previously classified as 

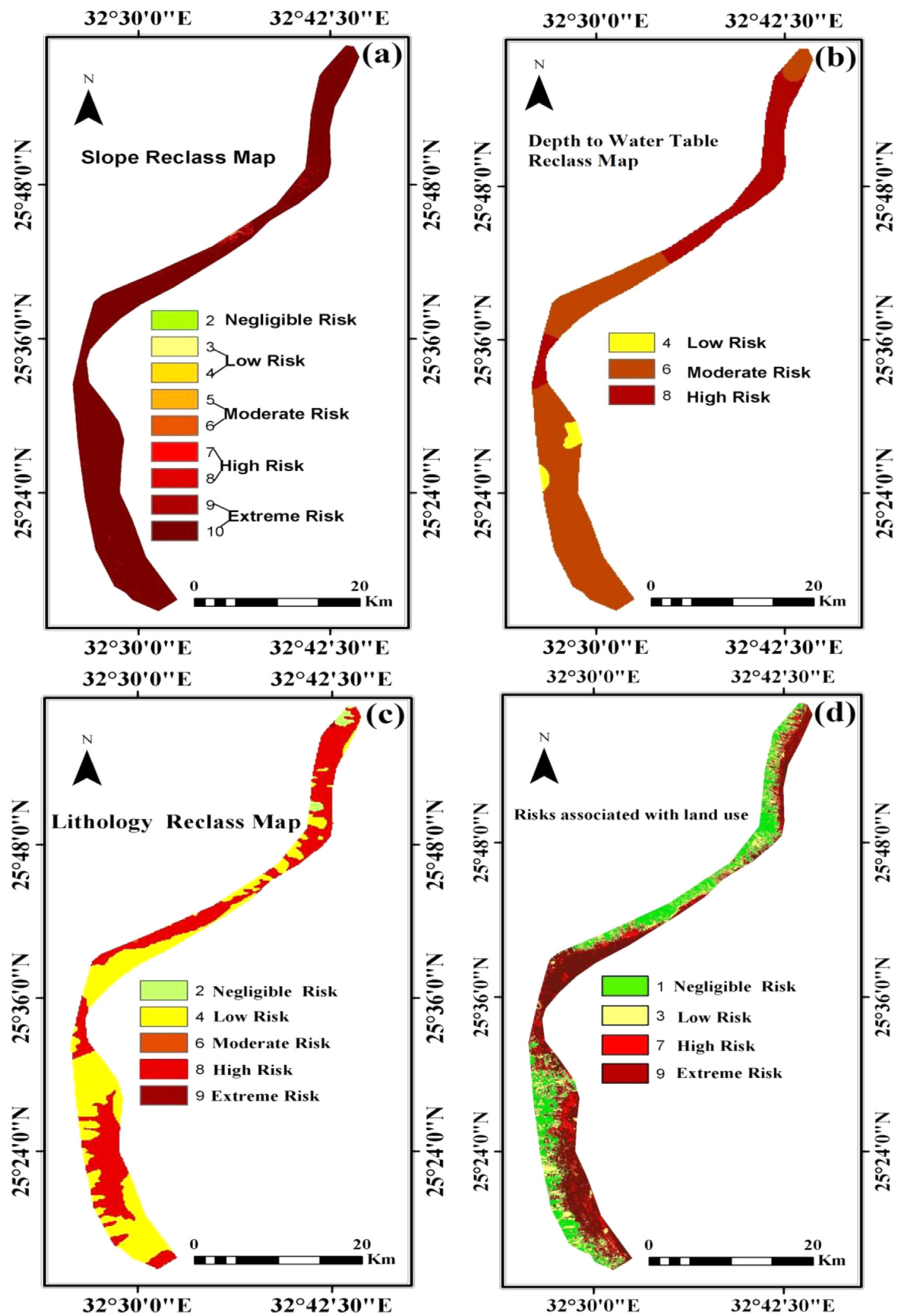

Fig. 7. Spatial distribution of hazards related to (a) Topographic slope (b) Depth to the water table (c) Lithology, (d) Land uses in the study area.

intrinsically vulnerable.

The map of groundwater vulnerability to nitrate pollution (Fig. 9) showed that there was a west-east gradient of specific vulnerability that ranges from negligible values to extreme values. These extreme values were located along the eastern part of the study area, where most of the human activities (principally irrigated land), are concentrated. So, according to the LU-IV procedure $38 \%, 14 \%, 11 \%$ and $37 \%$ of the area showed extreme, high, low and negligible levels of vulnerability to nitrate pollution, respectively. 

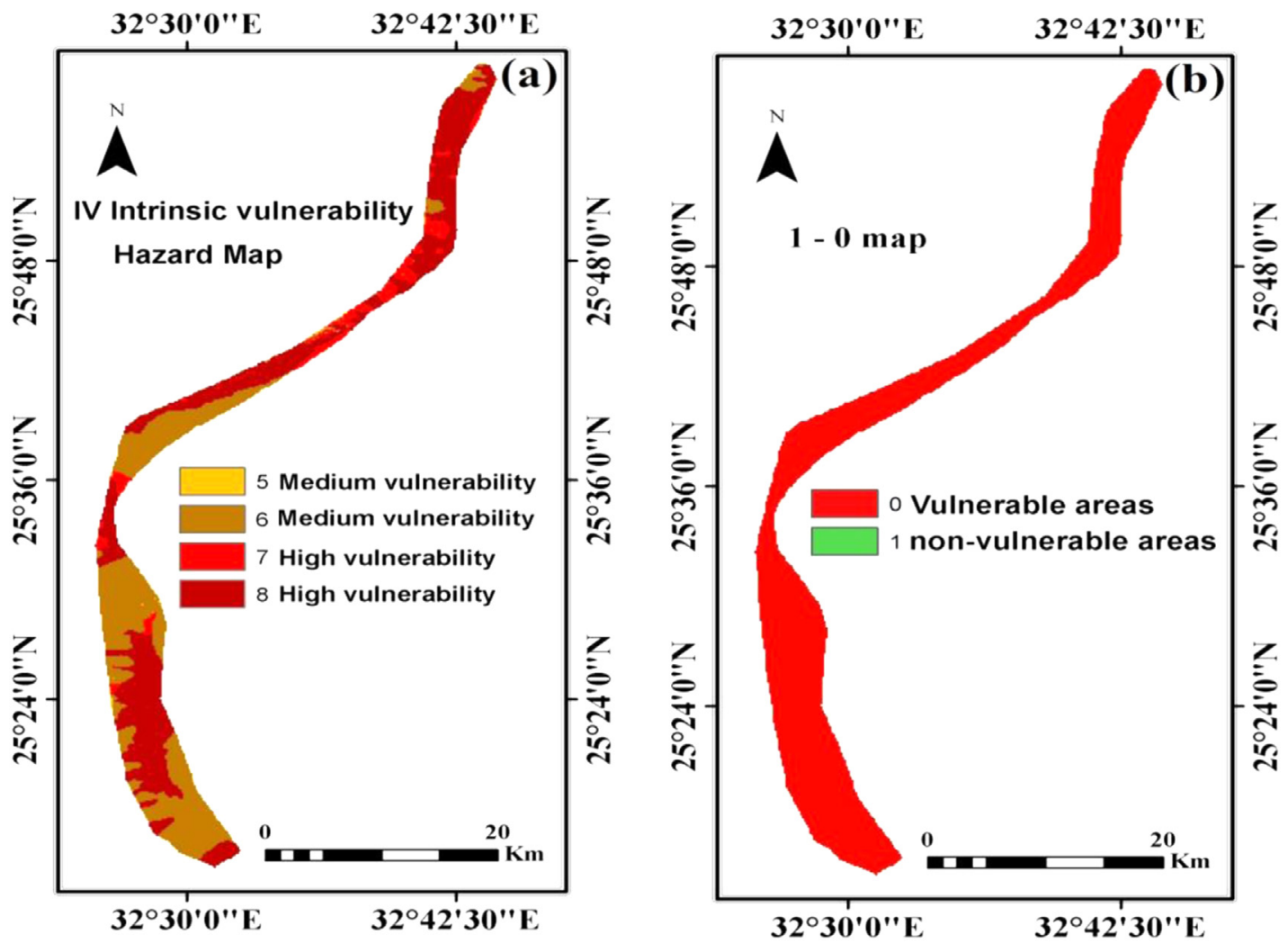

Fig. 8. (a) Groundwater intrinsic vulnerability (IV index based on three parameters $[(L+D+T) / 3]$ and (b) the intrinsic vulnerability $1-0$.

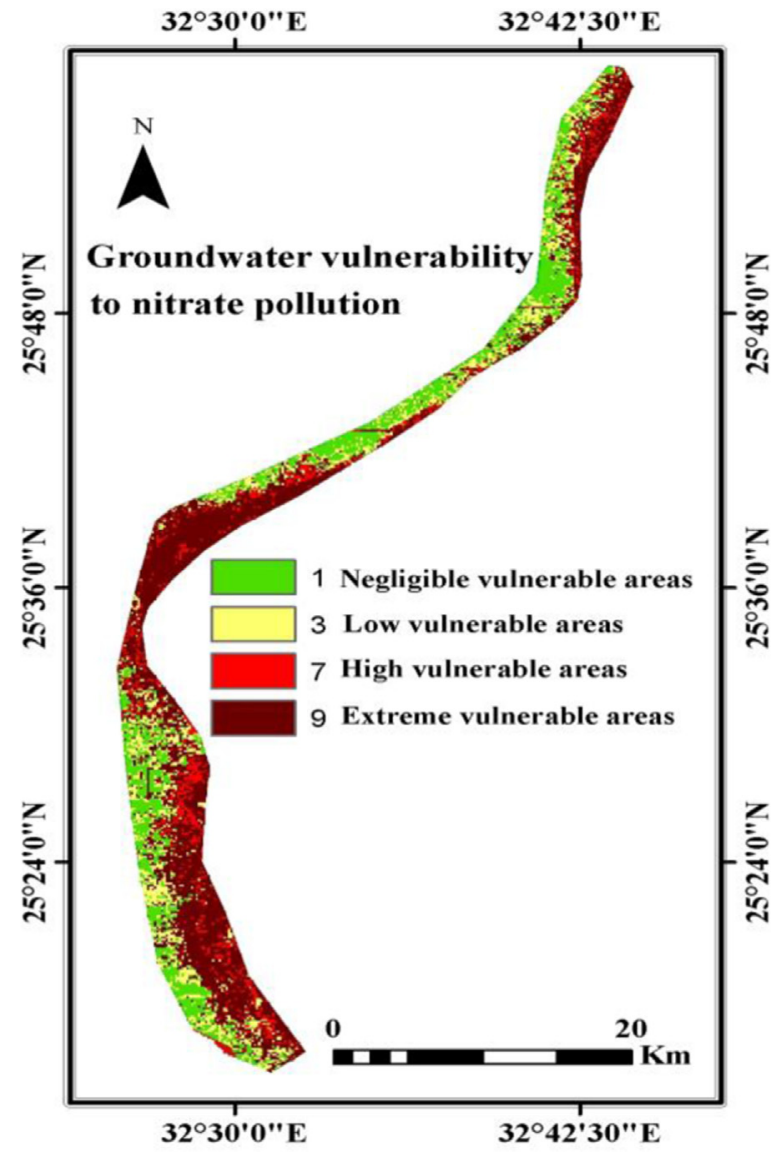

Fig. 9. The map of the specific groundwater vulnerability to nitrate pollution based on the LU-IV procedure.

\section{Conclusion}

Groundwater nitrate contents in the western desert fringes of Luxor Governorate revealed high levels of pollution $\left(\left[\mathrm{NO}_{3}^{-}\right] \geq 50 \mathrm{mg} \mathrm{L}^{-1}\right)$ in a large part of its territory. It was also observed high levels of $\mathrm{Pb}$ and $\mathrm{Cd}$ above the limits established by WHO (2011). The excess nitrate and metals $(\mathrm{Pb}$ and $\mathrm{Cd})$ in groundwater were explained from the non-optimised applications of $\mathrm{N}$ - and P-fertilizers (respectively) in agricultural crops in the area.

According to the IV index, the intrinsic groundwater vulnerability map showed medium and high levels of vulnerability in $62 \%$ and $38 \%$ of the study area, respectively associated with natural (geological, topographic, and hydrological) attributes. According to the LU-IV procedure, $52 \%$ of the study area showed high $(14 \%)$ to extreme (38\%) levels of vulnerability to nitrate pollution. From the present research, it was concluded that the irrigated and urban areas should be considered as NVZ. In these zones, farmers should be required to comply with specific measures (including optimization of water and $\mathrm{N}$ - and P-fertilizers applications) in order to restore water quality.

\section{Acknowledgements}

The authors would like to thank the Geological Sciences Department, National Research Centre, Egypt for Lab and field work facilities.

\section{References}

Abd El Hadi, A.H., Marchand M., 2013. Country Report on Egyptian Agriculture and Summary of IPI Experiments. e-ifc No. 33, March 2013, 14/35-20/35.

Abd El-Bassier, M.A., 1997. Hydrogeological and hydrochemical studies of the Quaternary Aquifer in Qena Governorate, Egypt. (M.Sc. Thesis). Fac. Sci. Assiut Univ. Egypt, p. 163.

Abdalla, F.A., Ahmed, A.A., Omer, A.A., 2009. Degradation of groundwater quality of quaternary aquifer at Qena, Egypt. J. Environ. Stud. 1, 19-32.

Ahmed, A.A., 2009. Using Generic and Pesticide DRASTIC GIS-based models for 
vulnerability assessment of the Quaternary aquifer at Sohag, Egypt. Hydrogeol. J. 17, 1203-1217.

Ahmed, A.A., Fogg, G.E., 2014. The impact of groundwater and agricultural expansion on the archaeological sites at Luxor, Egypt. J. Afr. Earth Sci. 95, 93-104.

Aller, L., Bennet, T., Leher, J.H., Petty, R.J., Hackett, G., 1987. DRASTIC: A Standardized System for Evaluating Ground Water Pollution Potential Using Hydrogeological Settings. US. Environmental Proctection Agency, Ada Oklahoma, pp. 74820 (EPA 600/2-87-035, 662 p).

APHA (American Public Health Association), 1995. Standard Methods for the Examination of Water and Wastewater, 19th ed. APHA, Washington.

Arauzo, M., 2017. Vulnerability of groundwater resources to nitrate pollution: a simple and effective procedure for delimiting Nitrate Vulnerable Zones. Sci. Total Environ. 575, 799-812.

Arauzo, M., Martínez-Bastida, J.J., 2015. Environmental factors affecting diffuse nitrate pollution in the major aquifers of central Spain: groundwater vulnerability vs. groundwater pollution. Environ. Earth Sci. 73, 8272-8286.

Arauzo, M., Valladolid, M., Martínez-Bastida, J.J., 2011. Spatio-temporal dynamics of nitrogen in river-alluvial aquifer systems affected by diffuse pollution from agricultural sources: implications for the implementation of the Nitrate Directive. J. Hydrol. 411, 155-168.

Asmoay, A.S.A., 2017. Hydrogeochemical Studies on the Water Resources and Soil Characteristics in the Western Bank of the River Nile between Abu Qurqas and Dayr Mawas, El Minya Governorate, Egypt (Ph.D. Thesis). Faculty of Science, Al Azhar University, Egypt (254p).

Avtar, R., Kumar, P., Surjan, A., Gupta, L.N., Roychowdhury, K., 2013. Geochemical processes regulating groundwater chemistry with special reference to nitrate and fluoride enrichment in Chhatarpur area, Madhya Pradesh, India. Environ. Earth Sci. 70 (4), 1699-1708.

Camargo, J.A., Alonso, Á., 2006. Ecological and toxicological effects of inorganic nitrogen pollution in aquatic ecosystems: a global assessment. Environ. Int. 32, 831-849.

Chkirbene, A., Tsujimura, M., Charef, A., Tanaka, T., 2009. Hydro-geochemical evolution of groundwater in an alluvial aquifer: case of Kurokawa aquifer, Tochigi prefecture, Japan. Desalination 246, 485-495.

CONOCO, 1987. Geological Map of Egypt, Scale 1: 500,000, NG 36 SW Luxor. The Egyptian General Petroleum Corporation, Cairo (EGPC), Egypt.

Council of the European Communities, 1991. Directive 91/676/EEC Concerning the Protection of Waters Against Pollution Caused by Nitrates from Agricultural Sources. Council of the European Communities, Brussels.

Dubrovsky, N., Hamilton, P., 2010. Nutrients in the nation's streams and groundwater: national findings and implications. U.S. Geol. Surv., Rest., Va. Fact. Sheet 2010-3078. 〈http://pubs.usgs.gov/fs/2010/3078/〉 (Acessed 25 February 2014).

El Tahlawi, M.R., Abo-El Kassem, M., Baghdadi, G.Y., Saleem, H.A., 2016. Assessment of groundwater vulnerability - a case study. Int. J. Adv. Remote Sens. GIS 5 (2), 1561-1579.

El-Aassar, E.M., Hussien, R.A., Ghoubachi, S.Y., 2016. Groundwater quality and vulnerability assessment in the new reclamation areas, assuit governorate, West Nile River, Egypt. J. Am. Sci. 12 (11).

ESRI, 2013. ArcGIS for Desktop: Release 10.2. Environmental Systems Research Institute, Redlands, California.

European Commission, 2000. Nitrates Directive (91/676/EEC). Status and Trends of Aquatic Environment and Agricultural Practice. Development guide for Member States' Reports. Directorate-General for Environment, Brussels.

Fernández-Luqueño, F., López-Valdez, F., Gamero-Melo, P., Luna- Suárez, S., AguileraGonzález, E.N., Martínez, A.I., García- Guillermo, M.S., Hernández-Martínez, G., Herrera-Mendoza, R., Álvarez-Garza, M.A., Pérez-Velázquez, I.R., 2013. Heavy metal pollution in drinking water - a global risk for human health: a review. Afr. J. Environ. Sci. Technol. 7 (7), 567-584.
García, G.M., Hidalgo, M.D.V., Blesa, M.A., 2001. Geochemistry of groundwater in the alluvial plain of tucuman province, argentina. Hydrogeol. J. 9 (6), 597-610.

Gemail, K.S., El Alfy, M., Ghoneim, M.F., Shishtawy, A.M., Ahmed, Abd El-Bary, M., 2017. Comparison of DRASTIC and DC resistivity modeling for assessing aquifer vulnerability in the central Nile Delta, Egypt. Environ. Earth Sci. 76, 350. https://doi.org/ $10.1007 / \mathrm{s} 12665-017-6688-4$.

Hasan, M.R., Khan, M.Z.H., Khan, M., Aktar, S., Rahman, M., Hossain, F., Hasan, A.S.M.M., 2016. Heavy metals distribution and contamination in surface water of the Bay of Bengal coast. Cogent Environ. Sci. 2, 1140001.

Kang, J., Zhao, L., Li, R., Mo, H., Li, Y., 2016. Groundwater vulnerability assessment based on modified DRASTIC model: a case study in Changli County, China. Geocarto Intern. 32 (7). https://doi.org/10.1080/10106049.2016.1167969.

Li, Y., Zhang, J., 1999. Agricultural diffuse pollution from fertilisers and pesticides in China. War. Sci. Technol. 39 (3), 25-32.

Melegy, A.A., Shaban, A.M., Hassaan, M.M., Salman, S.A., 2014. Geochemical mobilization of some heavy metals in water resources and their impact on human health in Sohag governorate, Egypt. Arab. J. Geosci. 7, 4541-4552.

Moghaddam, H.K., Jafari, F., Javadi, S., 2015. Evaluation Vulnerability of Coastal aquifer via GALDIT model and comparison with DRASTIC Index using Quality parameters. Hydrol. Sci. J. https://doi.org/10.1080/02626667.2015.1080827.

Moussa, A.B., Zouari, K., Oueslati, N., 2009. Geochemical study of groundwater mineralization in the grombalia shallow aquifer, north-eastern Tunisia: implication of irrigation and industrial waste water accounting. Environ. Geol. 58 (3), 555-566.

Omer, A.A.M., 1996. Geological, Mineralogical and Geochemical Studies on the Neogene and Quaternary Nile basin deposits, Qena- Assiut stretch, Egypt. Ph.D. Thesis. Geol. Dept., Fac. Sci., South Valley Univ., Egypt.

Paul, D., 2017. Research on heavy metal pollution of river Ganga: a review. Ann. Agrar. Sci. https://doi.org/10.1016/j.aasci.2017.04.001.

Rahman, A., 2008. A GIS based DRASTIC model for assessing groundwater vulnerability in shallow aquifer in Aligarh, India. Appl. Geogr. 28, 32-53.

Richards, L.A., 1954. Diagnosis and Improvement of Saline and Alkali Soils. USDA Agric. Handb. 60. USDA, Washington, DC.

Sajil, K.P.J., Jegathambal, P., James, E.J., 2014. Chemometric evaluation of nitrate contamination in the groundwater of a hard rock area in Dharapuram, South India. Appl. Water Sci. 4, 397-405.

Salman, S.A., Elnazer, A.A., El Nazer, H.A., 2017. Integrated mass balance of some heavy metals fluxes in Yaakob village, south Sohag, Egypt. Int. J. Environ. Sci. Technol. 14, 1011-1018.

Suthar, S., Bishnoi, P., Singh, S., Mutiyar, P.K., Nema, A.K., Patil, N.S., 2009. Nitrate contamination in groundwater of some rural areas of Rajasthan, India. J. Hazard. Mater. 171 (1-3), 189-199.

Sutton, M.A., Howard, C.M., Erisman, J.W., Billen, G., Bleeker, A., Grennfelt, P., van Grisven, H., Grizzetti, B., 2011. The European Nitrogen Assessment: Sources, Effects and Policy Perspectives. Cambridge University Press, Cambridge.

Thirumalaivasan, D., Karmegam, M., Venugopal, K., 2003. AHP-DRASTIC: software for specific aquifer vulnerability assessment using DRASTIC model and GIS. Environ. Model. Softw. 18, 645-656.

Verma, R., Dwivedi, P., 2013. Heavy metal water pollution- a case study. Recent Res. Sci. Technol. 5 (5), 98-99.

WHO, 2011. Guideline for Drinking Water Quality, 4th ed. World Health Organization, Geneva.

Wolfe, A.H., Patz, J.A., 2002. Reactive nitrogen and human health: acute and longterm implications. Ambio 31 (2), 120-125.

Yang, Q., Wang, L., Ma, H., Yu, K., Martín, J.D., 2016. Hydrochemical characterization and pollution sources identification of groundwater in Salawusu aquifer system of Ordos Basin, China. Environ. Pollut. 216, 340-349. 